\title{
PERSPECTIVES ON AUDIT QUALITY: AN ANALYSIS
}

\author{
Noor Adwa Sulaiman*, Fatimah Mat Yasin and Rusnah Muhamad
}

\begin{abstract}
Research aim: This paper reviews the research literature and publications relevant to audit quality. The authors identify three main perspectives (academic research, professional and regulatory) related to audit quality that could add to our understanding of the concepts and factors affecting audit quality in practice. For each reviewed perspective, the authors present and summarise the key findings.

Design/ Methodology/ Approach: This study reviews a total of 84 empirical studies and publications ranging from year 1980 to year 2016. Further, this paper links academic research to publications on the topic issued by professional practitioners and regulators.

Research findings: Based on the analysis, the review reveals three main findings. First, the review identifies multifaceted concepts of audit quality and the various academic research approaches that have been carried out to assess audit quality. Second, audit quality in practice is not only affected by various internal factors within the accounting firms but is also influenced by various contextual factors in which the accounting firms operate. Third, much of the prior research employs an archival approach that potentially provides limited information about the effect of the contextual setting in actual audit practices, which is important to enhance our understanding of audit quality.
\end{abstract}

Theoretical contribution/ Originality: It provides some guidance for future academic research related to audit quality.

Practitioner/ Policy implication: The research and reports reviewed in this paper will be useful to researchers, audit practitioners, policymakers and others who are concerned with the quality of audit services to understand the various conceptions of audit quality and the important factors affecting audit quality in practice.

Research limitation/ Implications: The analysis of the audit quality from the three main perspectives provided in this study pave the way for embarking on promising and relevant future research, which is needed to further substantiate and enrich the academic understanding on concepts and factors affecting audit

*Corresponding Author: Noor Adwa Sulaiman, $\mathrm{PhD}$ is a Senior Lecturer in the Faculty of Business and Accountancy, University of Malaya, 50603 Kuala Lumpur, Malaysia. Email: adwa@um.edu.my

Fatimah Mat Yasin, PhD is an Accounting Lecturer at the Kulliyyah of Economics and Management Sciences, International Islamic University Malaysia, 50728 Kuala Lumpur, Malaysia. Email: fatimahmy@iium.edu.my

Rusnah Muhamad, PhD is an Associate Professor in the Faculty of Business and Accountancy, University of Malaya, 50603 Kuala Lumpur, Malaysia. Email: rusnah@um.edu.my 
quality. More research is needed to understand this issue better and to move towards a policy resolution.

Keywords: Audit Quality, Auditing, Literature Review, Research Opportunities

Type of manuscript: Literature review

JEL Classification: M41, M42, M48, L84

\section{Introduction}

Audit quality and the factors that affect quality have been the subject of interest in academic, practitioner and regulatory debates about auditing following a series of corporate collapses. As a result, there have been considerable developments in the auditing, financial reporting and governance regimes by regulators and professional bodies in the name of enhancing audit quality. Regulators, such as the International Auditing and Assurance Standards Board (IAASB), have published a framework for audit quality, which discusses various pertinent factors affecting audit quality in practice (IAASB, 2014). Earlier, the Financial Reporting Council (FRC) released a discussion paper identifying the drivers for audit quality (FRC, 2008). In like manner, the Institute of Chartered Accountants in England and Wales (ICAEW) (2002) issued a report to frame concepts and various factors affecting audit performance. Similarly, research in the academic domain has examined the concepts and various factors affecting quality differentiation between audit firms and auditors (see Watkins, Hillison \& Morecroft, 2004; Francis, 2011; Knechel, Krishnan, Pevzner, Shefchik \& Velury, 2013; Simnett, Carson \& Vanstraelen, 2016) for a review of the literature). ${ }^{1}$

Although initiatives by regulators and professional practitioners influence the contemporary understanding concerning the concepts of audit quality, neither party have defined the term precisely. Research in the professional literature is inclined to define audit quality as conformance to the auditing standards during audit performance (Krishnan \& Schauer, 2001). In comparison, various academic research approaches have conceptualized and measured audit quality in several ways including a combination of measures linking inputs (such as size of audit firm and audit fees) to audit outcomes (such as financial reporting quality and accurate audit opinion) (Feroz, Park, \& Pastena, 1991; Becker, Defond, Jiambalvo \& Subramanyam, 1998; Gul, Sun, \& Judy, 2003), process measures that are related to auditor performance in the audit process (Sutton, 1993; Malone \& Roberts, 1996), and studies of the perceptions of the users and preparers of financial statements on audit quality (Schroeder, Solomon, \& Vickrey, 1986; Carcello, Hermanson, \& McGrath, 1992; Duff, 2009; Daniels \& Booker, 2011; Fontaine, 
Khemakhem, \& Herda, 2016). As a whole, there has been little agreement on a unified definition and measure of audit quality (Krishnan \& Schauer, 2000; FRC, 2008), which might be due to the unobservable features of audit quality (Power, 1997). In addition, the definition or understanding of audit quality may be different from the perspectives of audit participants (e.g., investors, regulators and audit committees) in the audit market because of their different roles and expectations (Sutton, 1993). Consequently, audit participants employ different conceptions and approaches to its assessment (Rasmussen \& Jensen, 1998; Watkins et al., 2004). Hence, operationalizing the concepts of audit quality and the influential factors are open to further investigation (Nelson \& Tan, 2005; Knechel et al., 2013).

The purpose of this paper is to review prior research and publications that are primarily drawn from the arena of regulatory policy on auditing related to audit quality from three different perspectives: academic, professional practitioners, and regulators. This paper seeks to review the literature and publications in order to develop an understanding of the multiple concepts ascribed to audit quality and provide a broader viewpoint of the various debates that affect contemporary understanding of audit quality. Primarily, it identifies and synthesizes the key research themes, thereby providing a timely summary for researchers, practitioners and regulators alike, and the research gaps that need to be addressed in future research. This paper makes a twofold contribution to the existing literature. First, it provides a greater understanding of the concepts and factors affecting audit quality from various viewpoints. Second, the analysis of academic research highlights state-of-the-art audit quality and the dominant approaches in its research. This serves as a source of reference for future research by providing an agenda for further work specific to understanding audit quality within the social and organizational context of audit practices.

The remainder of this paper is organized as follows. Section 2 describes the methodology of the study. Section 3 reviews and summarizes the literature and publications dealing with audit quality. Section 4 provides discussion and research opportunities. Section 5 concludes the paper.

\section{Methodology}

The approach used in this study is an iterative review of the literature and publications relevant to audit quality. This study reviews a total of 84 empirical studies and publications ranging from year 1980 to year 2016. For each reviewed perspective of audit quality, the authors present 
a summary of the key findings - concepts and factors affecting audit quality - and identify areas for future research. Further, this paper links academic research to publications on the topic issued by professional practitioners and regulators.

The research design starts with an extensive search of the literature and publications through academic databases, such as Business Source Complete, Emerald, Proquest, JSTOR, Science Direct, and Sage Journals Online, and the websites of regulators and professional bodies, such as the FRC, IAASB, and ICAEW. Related keywords, such as audit quality, auditing, perceptions, audit process and audit performance are used to identify relevant literature and reports. The authors consider the keywords as being prevalent in audit quality research. The abstract and main body of the text are read to ensure the paper's relevance to the study, and irrelevant papers are eliminated. Microsoft Excel is used to tabulate key information from the papers, such as authors, journal, year of publication, keywords, objectives of the study, methodology and key findings to identify papers that deal directly with audit quality. The tabulation provides a reference list that improves the analysis and rigour of the study.

\section{Findings: Perspectives of Audit Quality}

This section presents the results of our analysis of the conceptions and factors affecting audit quality based on the papers selected for this review. Figure 1 illustrates the different viewpoints of the review.

\subsection{Academic Research Perspectives of Audit Quality}

The first perspective of audit quality is a discussion on empirical research from the academic literature. In general, academic literature related to audit quality can be categorized into three main strands: i) inputs and outcomes related to audit quality, ii) audit process and audit quality, and iii) perceptions of audit quality. Table 1 provides a summary of the review of the key literature and relevant publications.

\subsubsection{Inputs and Outcomes Related to Audit Quality}

The first strand of research employs the market-based data (archival) approach and focuses on the association between the proxies for 'input' and 'output' related to audit quality. The review of academic research reveals that the investigation of 'input' and 'output' is largely built around the definition of audit quality proposed by DeAngelo (1981a; 1981b). For DeAngelo, audit quality refers to the ability of the auditors to detect and report material misstatements, which reflects two key 
determinants of audit quality: the competence and independence of the professional auditors. Given the unobservable features of audit quality inability to examine the audit working papers or observe audit performance - various proxies for audit quality have been used (such as size and industry specialist of audit firms) to test the effects of the proxies on the independence and competence of the auditors. As such, 'input' variables (such as audit firm size, audit fees, non-audit fees, and audit tenure) and 'output' quality (such as quality of earnings, litigation, accurate audit opinion and regulatory sanctions) have been extensively examined to assess audit quality (Palmrose, 1988; Feroz, Park \& Pastena, 1991; Davidson \& Neu, 1993; Gul et al., 2003; Ruiz-Barbadillo, GomezAguilar, Fuentes-Barbera \& Garcia-Beneu, 2004).

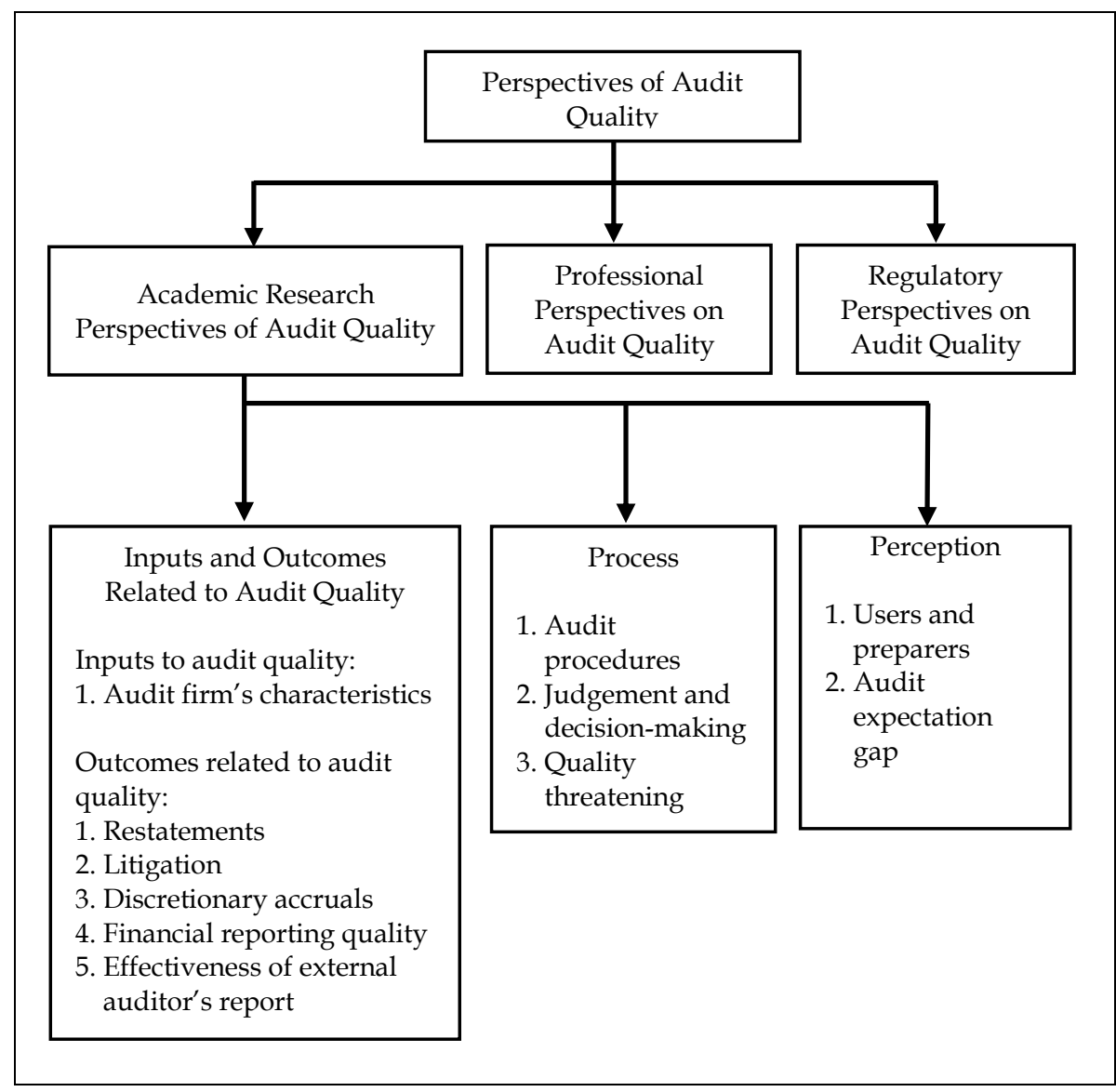

Figure 1. Perspectives of Audit Quality 
In general, it is argued that the size of the audit firms could influence the variation in audit quality. Larger audit firms are associated with high audit quality. This is due to the availability of resources, less economic dependence on single clients and greater loss of reputation for big size audit firms, which causes the firms to perform high-quality audits, and enhance the propensity of the auditors to issue high-quality financial statements or accurate audit opinion. Although mixed results have been reported, prior research has shown that auditors from larger audit firms are more competent than those from smaller firms due to the ability of the firms to hire skilled employees and provide rigorous training, which is associated with high audit quality (Guy, Ahmed \& Randal, 2010; DeFond \& Lennox, 2011; Sundgren \& Svanström, 2014). In addition, the big size audit firms are able to form accurate audit opinion because of their ability to detect more errors and omissions in the financial statements due to their more developed and structured audit approach (Carcello \& Hermanson, 1995; Lowensohn, Johnson, Elder, \& Davies, 2007; Al-Ajmi, 2009). The audited financial statements of clients of big size audit firms are also said to contain less earnings manipulation or restatements because the audit firms are more conservative in reporting, less economically dependent on the audit client and have an incentive to protect their professional reputation, which restricts the aggressive behaviour of corporate managers (Feroz, 1991; DeFond, Raghunandan, \& Subramayam, 2002; Kim, Chung, \& Firth, 2003; Chen, Lin and Zhou, 2005; Lee \& Humphrey, 2006; Chin \& Chi, 2009; Li \& Chen, 2011).

Table 1. Summary of Key Review

\begin{tabular}{|c|c|c|}
\hline $\begin{array}{l}\text { Perspective of } \\
\text { Audit Quality }\end{array}$ & Domain/ Studies & Main Findings/ Research Gap \\
\hline $\begin{array}{l}\text { Inputs and } \\
\text { Outcomes } \\
\text { Related to } \\
\text { Audit Quality }\end{array}$ & $\begin{array}{l}\text { Audit firm's characteristics and } \\
\text { outcomes related to audit quality: } \\
\text { Simunic (1984); Palmrose (1988); } \\
\text { Feroz et al. (1991); Davidson and } \\
\text { Neu (1993); Dye (1993); Carcello } \\
\text { and Hermanson (1995); Frankel, } \\
\text { Johnson and Nelson (2002); Gul et } \\
\text { al. (2003); Kinney, Palmrose and } \\
\text { Scholz (2004); Ruiz-Barbadillo et } \\
\text { al. (2004); Wu (2006); Hoitash, } \\
\text { Markelevich and Barragato (2007); } \\
\text { Lowensohn et al. (2007); } \\
\text { Caramanis and Lennox (2008); } \\
\text { Guy et al. (2010); Bliss, Gul and } \\
\text { Majid (2011); DeFond and Lennox } \\
\text { (2011); Sundgren and Svanström } \\
\text { (2014); Eshleman and Guo (2014); }\end{array}$ & $\begin{array}{l}\text { The association between the } \\
\text { 'input' of audit quality (i.e., } \\
\text { audit firm size, audit fees, } \\
\text { non-audit fees, and audit } \\
\text { tenure) and 'output' of audit } \\
\text { quality (i.e., quality of } \\
\text { earnings, litigation, accurate } \\
\text { audit opinion and regulatory } \\
\text { sanctions) provides } \\
\text { inconsistent results. } \\
\text { Limited information about } \\
\text { audit practices that contribute } \\
\text { to high audit quality. } \\
\text { The need for additional } \\
\text { research beyond the } \\
\text { association between the } \\
\text { proxies for audit quality and }\end{array}$ \\
\hline
\end{tabular}




\begin{tabular}{|c|c|c|}
\hline $\begin{array}{l}\text { Perspective of } \\
\text { Audit Quality }\end{array}$ & Domain/ Studies & Main Findings/ Research Gap \\
\hline \multirow[b]{2}{*}{ Process } & $\begin{array}{l}\text { Cahan and Sun (2015); Bell, } \\
\text { Causholli and Knechel (2015) }\end{array}$ & related outcomes. \\
\hline & $\begin{array}{l}\text { Audit procedures: Cushing and } \\
\text { Loebbecke (1986); Bamber and } \\
\text { Snowball (1988); Morris and } \\
\text { Nichols (1988); Mutchler and } \\
\text { Williams (1990); Icerman and } \\
\text { Hillison (1991); Eining, Donald } \\
\text { and James (1997); Arnold and } \\
\text { Sutton (1998); Asare and Wright } \\
\text { (2004); Wilks and Zimbelman } \\
\text { (2004); Curtis (2006); Agoglia, } \\
\text { Beaudoin and Tsakumis (2009) } \\
\text { Judgement and decision making: } \\
\text { Libby and Luft (1993); Ashton and } \\
\text { Ashton (1995); Gramling (1999); } \\
\text { Earley (2002); Ng and Tan (2003); } \\
\text { Solomon and Trotman (2003); } \\
\text { Nelson and Tan (2005); Lehmann } \\
\text { and Norman (2006); Nolder and } \\
\text { Riley (2014); Mala and Chand } \\
\text { (2015); Kang, Trotman and } \\
\text { Trotman (2015); Brown-Liburd, } \\
\text { Issa and Lombardi (2015) } \\
\text { Quality threatening behavior: } \\
\text { Lightner, Adams and Lightner } \\
\text { (1982); Alderman and Deitrick } \\
\text { (1982); Margheim and Pany (1986); } \\
\text { Kelley and Margheim (1990); } \\
\text { McNair (1991); Otley and Pierce } \\
\text { (1995); Malone and Roberts (1996); } \\
\text { Otley and Pierce (1996b); Willet } \\
\text { and Page (1996); Kelley, Margheim } \\
\text { and Pattison (1999); Lord and } \\
\text { DeZoort (2001); Lee (2002); } \\
\text { Herrbach (2001); Pierce and } \\
\text { Sweeney (2003); Pierce and } \\
\text { Sweeney (2004); Sweeney and } \\
\text { Pierce (2004); Pierce and Sweeney } \\
\text { (2005); Dowling and Leech (2014) }\end{array}$ & $\begin{array}{l}\text { Evidence pertaining to the } \\
\text { audit procedures and their } \\
\text { effects on the audit process } \\
\text { has been mixed. } \\
\text { The findings of quality of } \\
\text { audit judgment studies may } \\
\text { not be generalizable or } \\
\text { applicable in various } \\
\text { situations. } \\
\text { The findings of QTB studies } \\
\text { are inconsistent and } \\
\text { contradictory. } \\
\text { Overall, limited attention has } \\
\text { been given to the audit } \\
\text { process in understanding the } \\
\text { audit quality. Most of the } \\
\text { literature does not address the } \\
\text { actual audit process in } \\
\text { practice. } \\
\text { Overall, limited attention has } \\
\text { been given to the audit } \\
\text { process in understanding the } \\
\text { audit quality. Most of the } \\
\text { literature does not address the } \\
\text { actual audit process in } \\
\text { practice. }\end{array}$ \\
\hline Perception & $\begin{array}{l}\text { Users and preparers: Schroeder et } \\
\text { al. (1986); Knapp (1991); Carcello } \\
\text { et al. (1992); Behn, Carcello, } \\
\text { Hermanson and Hermanson } \\
\text { (1997); Sucher, Moizer and Zarova } \\
\text { (1998); Chen, Lin and Zhou (2001); } \\
\text { Duff, (2004); Duff (2009); Beattie, } \\
\text { Fearnley and Hines (2011); Smith }\end{array}$ & $\begin{array}{l}\text { The preparers, users, and } \\
\text { auditors rated audit quality } \\
\text { factors differently, which } \\
\text { indicates a lack of consensus } \\
\text { concerning what audit quality } \\
\text { means to the different } \\
\text { constituents of audit market } \\
\text { participants. }\end{array}$ \\
\hline
\end{tabular}




\begin{tabular}{|c|c|c|}
\hline $\begin{array}{l}\text { Perspective of } \\
\text { Audit Quality }\end{array}$ & Domain/ Studies & Main Findings/ Research Gap \\
\hline & $\begin{array}{l}\text { (2012); Gonthier-Besacier, } \\
\text { Hottegindre and Fine-Falcy (2016) }\end{array}$ & \\
\hline & $\begin{array}{l}\text { Audit expectation gap: Mautz and } \\
\text { Sharaf (1961); Wilcox and Smith } \\
\text { (1977); Wallace (1980); Porter } \\
\text { (1991); Humphrey, Moizer and } \\
\text { Turley (1992); Mills and Bettner } \\
\text { (1992); Percy (2007); Porter (1993); } \\
\text { Beattie and Fearnley (1995); Sikka, } \\
\text { Puxty, Willmott and Cooper } \\
\text { (1998); Brown, Gissel and Neely } \\
\text { (2016) }\end{array}$ & $\begin{array}{l}\text { Survey questionnaires or } \\
\text { experimental studies provide } \\
\text { limited understanding about } \\
\text { how audit practitioners, AC } \\
\text { members, and regulators } \\
\text { conceptualize the idea of } \\
\text { audit quality and its influence } \\
\text { on their process and activities, } \\
\text { since structured questions are } \\
\text { used to examine the issue. }\end{array}$ \\
\hline $\begin{array}{l}\text { Professional } \\
\text { Perspectives }\end{array}$ & $\begin{array}{l}\text { Main elements of audit quality in } \\
\text { practice: } \\
\text { Attributes of people within the } \\
\text { audit firms; policies and } \\
\text { procedures in governance and } \\
\text { control system of the audit firms; } \\
\text { factors which are outside of the } \\
\text { audit firm (ICAEW, 2002) }\end{array}$ & $\begin{array}{l}\text { The conception of audit } \\
\text { quality as proposed by } \\
\text { professionals highlight the } \\
\text { importance of various } \\
\text { contextual factors in } \\
\text { achieving audit quality in } \\
\text { practice. }\end{array}$ \\
\hline $\begin{array}{l}\text { Regulatory } \\
\text { Perspectives }\end{array}$ & $\begin{array}{l}\text { Key elements that can promote } \\
\text { high audit quality: the culture } \\
\text { within an audit firm; the skills and } \\
\text { personal qualities of audit partners } \\
\text { and staff (input); the effectiveness } \\
\text { of the audit process (including } \\
\text { audit judgment/ documentation; } \\
\text { the reliability and usefulness of } \\
\text { audit reporting (output); and the } \\
\text { factors outside the control of } \\
\text { auditors/contextual factors (FRC, } \\
\text { 2007: IAASB, 2014) }\end{array}$ & $\begin{array}{l}\text { - The regulators emphasized } \\
\text { the contextual factors in } \\
\text { achieving high-quality audit. }\end{array}$ \\
\hline
\end{tabular}

Audit quality is said to be better in larger firms due to the higher audit fees, which are believed to be related to the specialized knowledge of the audit firm and greater audit effort. In effect, auditors in larger audit firms are better able to detect material misstatements (Elitzur \& Falk, 1996; Caramanis \& Lennox, 2008). However, the evidence of this relationship is inconclusive. A number of prior studies have failed to identify any association between audit firm size and audit fees or industry specialization (Dye, 1993; Hoitash, Markelevich \& Barragato, 2007; Caramanis \& Lennox, 2008; Bliss, Gul, \& Majid, 2011; Eshleman \& Guo, 2014; Cahan \& Sun, 2015). Similarly, mixed findings have also been recorded concerning the association between non-audit fees and audit quality (ability to detect and report material misstatements) as a result of 
the 'knowledge spillover' (auditors gain greater understanding of the client and their business processes because of additional services) (Simunic, 1984; Frankel, Johnson, \& Nelson, 2002; Kinney, Palmrose \& Scholz, 2004; Wu, 2006; Bell, Causholli, \& Knechel, 2015). In like manner, audit tenure may reduce or increase audit quality. Long tenure is said to improve audit quality through the greater experience and knowledge that the auditors gather concerning the client's business, which enhances their ability to detect material misstatements (Johnson, Khurana \& Reynolds, 2002; Ghosh \& Moon, 2005; Stanley \& DeZoort, 2007; Manry, Mock, \& Turner, 2008; Bryan \& Reynolds, 2016). In contrast, long tenure could affect audit quality - auditor's ability to detect and report the misstatements. Longer tenure would make the auditors less sceptical and rigorous in audit procedures, and more complacent and reduce the capacity of the auditors to detect errors and misstatements (Shockley, 1982; Deis \& Giroux, 1992).

Overall, the academic evidence concerning an association between the 'input' of audit quality and 'output' of audit quality provides inconsistent results. Despite the significant contribution of this strand of research to our understanding of audit quality from the perspective of the association between the proxies for audit quality and the properties (such as earnings quality) of financial statements, it provides limited information about the audit practices that contribute to high audit quality. This suggests the need for additional research beyond the association between the proxies of audit quality and the related outcomes.

\subsubsection{The Audit Process and Audit Quality}

The second strand of academic research related to audit quality concentrates on examining the factors affecting audit quality including audit procedures, auditors' judgment and the behaviour or task performance during the audit process.

The literature has documented that the audit process can be impacted by the audit procedures used in conducting the audit. A number of studies have focused on the audit procedures by specifically examining the audit methods used in conducting the audit, the effects of the audit methods applied, as well as the decision aids applied in practice to develop new audit methods or procedures (Curtis, 2006). The different audit methods (Cushing \& Loebbecke, 1986) and decision aids (Eining et al., 1997; Arnold and Sutton, 1998; Asare and Wright, 2004) used have been documented as having a different influence on the various aspects of audit performance, which, in turn, can negatively or 
positively influence the audit quality (Bamber and Snowball, 1988; Morris and Nichols, 1988; Mutchler and Williams, 1990; Icerman and Hillison, 1991). For example, Wilks and Zimbelman (2004) find that the use of a holistic approach to assess the risks would result in an understatement of the fraud risk assessments compared to an approach that separately assesses the risk of fraud for different components. In all, the audit methods and decision aids are specifically adopted to direct and help an audit team conduct the audit in a systematic manner (Knechel et al., 2013).

However, evidence pertaining to the audit procedures and their effects on the audit process has been mixed. It has been documented that the use of decision aids and standardized checklists in the audit may reduce auditor performance, such as auditor professional judgment (Bamber and Snowball, 1988; Arnold and Sutton, 1998; Asare and Wright, 2004). External auditors tend to rely on the recommendations provided in the decision aids and checklists instead of using their professional judgment when it is needed. However, a number of studies (Eining, Donald, \& James, 1997; Wilks \& Zimbelman, 2004; Agoglia et al., 2009) have documented that the use of an expert system influences the professional judgment of the auditors, which assists them in differentiating the varying risks of management fraud.

As an audit has been defined as a process of judgment (Humphrey, 1997 ), some studies have investigated the audit process in the form of judgment decision-making (JDM) by the external auditor. Researchers have focused on the auditor's judgment and decision-making process in conducting the audit tasks including risk assessments, analytical procedures and evidence evaluation, auditor's correction decision, and going concern judgment (Nelson and Tan, 2005; Francis, 2011). A few factors have been identified as having a major influence on the auditor's performance in making a decision, such as ability, decision aids, multiperson judgement, heuristics and biases, knowledge and memory, probabilistic judgement, environment and motivation, and policy capturing (Libby \& Luft, 1993; Gramling, 1999; Ng \& Tan, 2003; Solomon \& Trotman, 2003; Mala \& Chand, 2015). For example, auditors with more experience tend to solve complex problems effectively (Nelson \& Tan, 2005; Lehmann \& Norman, 2006) and provide a better judgment decision on the valuation (Earley, 2002), which leads to higher audit quality. Similarly, the use of decision aids, such as the information system regulatory framework may change the way auditors make decisions and collect evidence; thus, leading to better judgment and decision-making (Brown-Liburd, Issa \& Lombardi, 2015; Kang, Trotman \& Trotman, 2015). 
Due to the differences in the types of work performed by the auditors and the absence of definitive measures for the quality of audit judgments, the findings of the studies may not be generalizable or applied in various situations (Ashton and Ashton, 1995; Nolder and Riley, 2014). Most studies on JDM have applied experimental or survey approaches to investigate the JDM in the audit process (Mala \& Chand, 2015). However, there is a lack of studies that explore JDM in practice.

Academic research has carried out analysis of audit quality through the assessment of auditors' behaviour during the audit process. This particular line of research concentrates on examining various types of 'quality threatening behaviour' (QTB) that would affect the ability of the auditors to detect material misstatements due to the failure to execute proper steps in audit engagement (Kelley \& Margheim, 1990; Herrbach, 2001). The vast majority of research in QTB is in the form of survey questionnaires (Sweeney \& Pierce, 2004). Prior research identifies QTB as performance that undermines the audit quality including premature sign off of the audit report, making superficial reviews of client's documents, reduction in sample size, failing to research technical issues, accepting weak client explanations, reliance on client work more than is appropriate, and reducing the amount of work performed to less than what the auditor would consider reasonable. In all, QTB is a serious concern because it affects audit quality as a result of incorrect audit opinion due to the inability to detect material misstatements (Sweeney \& Pierce, 2004).

Previous research findings concerning QTB have been inconsistent and contradictory. Some research has indicated that personality variables, such as moral development and ethics, and leadership style, have some influence on the QTB of the auditors (Kelley \& Margheim, 1990; Otley \& Pierce, 1995; Malone \& Roberts, 1996; Lord \& DeZoort, 2001; Pierce \& Sweeney, 2003; Pierce \& Sweeney, 2004). In most cases, auditors who possess high moral values and ethics are more likely not to perpetrate QTB during the performance of the audit. In like manner, leadership style and reviewer personality have also been associated with QTB. Extensive research on the incidence of QTB among audit staff has focused on the impact of budgets and deadlines. A number of prior studies show that the budget is associated with a high occurrence of QTB (Alderman \& Deitrick, 1982; Lightner, Adams \& Lightner, 1982; McNair, 1991; Otley \& Pierce, 1996b; Willet \& Page, 1996; Kelley, Margheim \& Pattison, 1999; Lee, 2002) whilst audit review procedures yield mixed results (Margheim \& Pany, 1986; Malone \& Roberts, 1996; Pierce \& Sweeney, 2005). Prior research suggests that budget is regarded as a form 
of performance measurement within the audit firm and may be a source of pressure that affects the performance of the auditor. In this case, auditors may spend less time on the audit in order to control audit costs that inhibit them from detecting material misstatements in the financial statements (McNair, 1991; Otley \& Pierce, 1996a; Pierce \& Sweeney, 2004; Peytcheva \& Gillett, 2012).

Overall, limited attention has been given to the audit process in understanding the audit quality. Prior studies have called for more studies to explore the audit quality regarding the audit process, which can help to improve overall audit quality (Nelson \& Tan, 2005; Francis, 2011; Knechel et al., 2013). This is supported by the UK Financial Reporting Council (FRC, 2008a), which identifies the effectiveness of the audit process as one of the key drivers of audit quality. It is important to realize that assessing the audit process can help to improve the understanding of the auditing in practice (what external auditors and clients perform and how they do it) and goes beyond the input and outcome indicators as proxies for audit quality. Further, it is argued that most of the literature does not address the actual audit process in practice. Therefore, more studies that explore the actual audit practices, which can be best captured using the qualitative approach is clearly warranted to complement the findings in the literature.

\subsubsection{Perceptions of Audit Quality}

The third strand of academic research concerns the perceptions of auditors, preparers (such as financial controllers) and users (such as audit committee, investors, and regulators) of financial statements on audit quality. The majority of the research draws on the concept of the independence and competence of professional auditors to assess audit quality. In general, prior research shows that users, preparers, and auditors rated the importance of various factors-auditors, firm and service quality - and their effect on audit quality in practice differently (Schroeder, Solomon, \& Vickrey 1986; Knapp, 1991; Carcello et al., 1992; Behn, Carcello, Hermanson \& Hermanson, 1997; Warming-Rasmussen and Jensen, 1998; Chen, Shome \& Su, 2001; Duff, 2004; Smith, 2012; Brown, Gissel, \& Neely, 2016). The audit practitioners, audit clients (as preparers of financial statements) and audit committee, in most cases, perceive the auditor factors to be an important determinant of audit quality (Schroeder et al., 1986; Knapp, 1991; Carcello et al., 1992; Behn et al., 1997; Sucher et al., 1998; Chen et al., 2001; Beattie, Fearnley \& Hines, 2011; Gonthier-Besacier, Hottegindre, \& Fine-Falcy, 2016). In this respect, service quality (such as attentiveness to clients and communication with 
audit clients) and auditors' technical attributes (reputation, capability, independence, expertise, and experience) are recognized as being important factors in delivering a high audit quality (Duff, 2004; 2009).

In comparison, auditors, preparers (such as financial controllers) and users (such as investors and regulators) rate the importance of audit firm factors (such as compliance with audit standards, the nature and extent of non-audit services, quality control standards, and professional certification for firm personnel) as low when they assess the audit quality (Schroeder et al., 1986; Carcello et al., 1992; Chen et al., 2001). Together with auditors and firms' factors, Beattie et al. (2011) carried out a study to examine the influence of the economic and regulatory factors on audit quality. This study shows that auditors, preparers and audit committees rate the factors related to firms, auditors and economic factors (communication between the external auditor and AC, financial background of AC, auditor independence and size of audit firm) as high. In comparison, the factors related to recent regulatory reforms (such as disclosure of non-audit fees paid to the auditor with a detailed breakdown, requirements of audit partner rotation, the risk of litigation, independent inspection, and publication of reports and risk of investigation by the FRRP) had minimal effect on the level of audit quality.

Overall, the preparers, users, and auditors rate audit quality factors differently, which indicates a lack of consensus concerning what audit quality means to the different participants in the audit market. This may be due to differences in the perceptions and expectations of various parties and the subjective nature of audit quality. Further, this strand of research highlights that service quality factors should be considered along with independence and competence, as suggested by DeAngelo (1981a; 1981b), to construct a broader concept of audit quality. In addition, most research in this area uses either survey questionnaires or experimental studies that provide limited understanding about how audit practitioners, AC members, and regulators conceptualize the idea of audit quality and its influence on their process and activities since structured questions are used to examine the issue.

\subsection{Professional Perspectives on Audit Quality}

The second perspective of audit quality focuses on empirical research and publications from the professional domain that are relevant to audit quality. In general, empirical research from the practitioner literature recognizes auditors' conformance to auditing standards during the conduct of the audit as one of the key concepts of audit quality (Cook, 
1987; Aldhizer, Miller, \& Moraglio, 1995; McConnell and Banks, 1998; Tie, 1999; Krishnan and Schauer, 2001). It is argued that auditors with good knowledge concerning auditing standards would be more likely to detect a material misstatement in the course of the audit. In 2002, the ICAEW, a professional accounting body in the UK, published a report entitled 'Audit Quality', which identifies a broader concept of audit quality by means of five factors that could drive audit quality in practice: (1) leadership, (2) people, (3) working practices, (4) monitoring quality practices, and (5) client relationships (ICAEW, 2002).

Further analysis of the report shows that the factors can be categorized into three main elements. The first element of audit quality is related to various attributes of people within the audit firms including individual's expertise, experience, skills, leadership and ethical values. The competence of professional auditors is important in arriving at good judgment. Both leadership and culture would influence the overall tone in the audit firms, and, hence, affect the delivery of the audit, as effective leaders are responsible for establishing and communicating the policies and procedures that promote audit quality. The second element is connected to the policies and procedures in the governance and control system of the audit firms and comprises the working practices, monitoring quality processes and firm's culture. In this respect, good working practices can be signified by means of proper audit planning, adequate audit performance and sufficient supervision by the superior. The final element of audit quality is connected to those factors outside of the audit firm, which include the working relationship between the auditors and other key participants of the audit market, especially the audit clients and audit committee. As a whole, the report explains the importance of people, together with the audit firm's wider policies and procedures, such as recruitment, reward and training, and systems of quality control (internal quality reviews - control reviews, audit reviews and compliance review) in supporting the quality of audit judgments as an indicator of audit quality. In addition, the working relationship between the auditors and audit clients as well as the audit committee is beneficial in facilitating the audit performance to attain high audit quality.

Overall, in brief, the conception of audit quality, as proposed by the ICAEW, emphasizes a wider view of audit quality that recognizes the influence of interaction within and between the firm and various internal and external factors in the auditing environment to audit quality. Analysis of the report highlights the importance of various contextual factors in achieving audit quality in practice. 


\subsection{Regulatory Perspectives on Audit Quality}

In the UK, the Financial Reporting Council (FRC) developed a framework of audit quality to provide guidelines to the users for assessing audit quality. In the framework, five key elements that can promote a high-quality audit were identified. These include 1) the culture within an audit firm; 2) the skills and personal qualities of the audit partners and staff; 3 ) the effectiveness of the audit process; 4 ) the reliability and usefulness of audit reporting; and 5) factors outside the control of auditors (FRC, 2007). These factors are important at three levels (individual, firm and institutional) to achieve a high-quality audit in which the relationship between these levels could contribute to the attainment of audit quality. The framework illustrates that the skills and personal qualities are important at the individual level, the culture of individual conduct is important at the firm-level, and, finally, interactions between the audit firms, audit clients, and the audit committees could influence the overall audit performance, which reflects the audit quality.

More recently, in 2014, IFAC supported a Framework for Audit Quality, which was developed by the International Auditing and Assurance Standards Board (IAASB). In this framework, four interrelated factors (inputs, outputs, interactions, and contextual factor) were described as the key attributes needed that contribute to high-quality audits. First, the input factors are more related to the external auditor quality attributes including the values, ethics, and attitudes of the auditors; knowledge and experience of auditors; as well as the effectiveness of the audit process and quality control procedures. Second, in terms of the output factors, the auditor's report is considered to be the primary output, which may contribute to the attainment of audit quality. Both factors (input and output) should be applied directly at the audit engagement level, firm level, and national level in order to achieve highquality audits. The third factor involves the interactions among the key stakeholders (external auditors and management, those charged with governance, users, and regulators) in that the way the stakeholders interact can have a particular impact on audit quality. These interactions, as described, can allow a dynamic relationship to exist between the inputs and outputs. Lastly, the contextual factors, such as corporate governance, legislative and regulatory requirements, are considered important to achieve high audit quality in that they may shape or impact the efficiency of the audit process. 
Overall, the regulators have emphasized the contextual factors in achieving a high-quality audit. The contextual factors are important as they can shape and influence the audit performance, and, ultimately, audit quality.

\section{Discussion and Research Opportunities}

The review of the different perspectives related to audit quality increases our understanding concerning the various concepts and factors affecting audit quality in practice. The analysis reveals that the majority of academic research applies the notions of the competence and independence of the auditors as the key concepts to measure audit quality. Despite the significant contribution of academic research on audit quality, this concept of audit quality is said to be narrow in focus, and the proxies that are used to measure it are still inconclusive (Duff, 2004). In addition, the majority of the research utilizes quantitative approaches, such as archival, surveys and experiments that fail to address or understand audit quality in its actual audit setting. It is important to note that the proxies of audit quality cannot be defined in strictly quantitative terms (Knechel et al., 2013). According to Humphrey (2008), even if the researcher introduces more variables or complexity into surveys or experiments or archival data, it is still debatable whether a researcher can capture or understand the pressure and influence of the audit environment on the quality of audit performance. As a result, these studies are unlikely to capture the actual audit practices, which are important to further understand audit quality.

It is interesting to highlight that publications related to audit quality issued by practitioners and regulators emphasize a broader concept of audit quality that recognizes the social and organizational context of the audit, which might influence audit quality (FRC, 2008; Humphrey, 2008; IAASB, 2014). Beyond the inputs and outputs of audit quality, the regulators concede the importance of the interactions between auditors and the different key participants in the audit market (such as management, those charged with governance, in particular, the audit committees and regulators) on audit quality. Equally important, the regulators recognize that various contextual factors, such as independent inspection regimes, internal audit relationship, relationship with management, corporate governance and financial reporting framework, competition and business practices, have an impact on audit quality. We encourage studies based on qualitative data, such as interviews and case studies that would allow greater in-depth insights into the reality of 
audit quality in practice. Hence, our review suggests a number of research opportunities.

First, more work can be carried out to understand the operations and processes involved in the audit, and, in consequence, their effects on audit quality. This is important because even if we identify a relationship, such as the size of the firm being linked to a higher quality signal, we do not know how the practitioners in a particular class of firm view the task and what they are doing, which gives rise to this link.

Second, more research can be carried out to understand how interactions between the external auditors and internal corporate governance mechanisms (audit committee and internal auditors) manifest in audit quality. There is a need for more research on the relationships and interfaces between the external auditors and these two parties.

Third, while prior research has acknowledged the importance of auditors' attributes, such as independence, not much is known about the effect on the auditors of the pressures in the auditing environment, such as commercialization and competition, and how the conflicts are resolved in practice.

Fourth, the complex nature of the auditor-client relationship warrants further investigation to capture how the relationships and interfaces influence audit quality.

Finally, evidence concerning how audit inspection regimes evaluate the quality and contribute to the achievement of high-quality auditing in practice is rather limited.

\section{Conclusions}

In this paper, we have reviewed the academic research and publications related to audit quality. Overall, we believe that the review provides wider concepts attributed to audit quality and the various contextual factors that can affect it. Hence, more research is needed to understand this issue better and to move towards a policy resolution. In addition, we have identified a number of important research opportunities and hope that auditing researchers will examine these issues to improve our knowledge about audit quality. Further, the analysis would be helpful for audit practitioners and policymakers in terms of understanding the key factors that affect audit quality, thus positioning the best strategies and policies in supporting it. 


\section{Note}

1. While this study focuses on examining the concepts and factors affecting audit quality from academic, professional and regulatory perspectives, the study by Watkins et al. (2004) focuses on examining the concepts of audit quality in the demand and supply framework and its association with financial reporting quality. In comparison, Francis (2011) examines the concepts of audit quality by analysing the factors associated with the engagement level quality, such as audit inputs and audit processes. Further, Knechel et al. (2013) examine the concepts of audit quality using the inputs, process and outcomes context. Finally, Simnett et al. (2016) examine published archival research and map the analysis to the IAASB Framework for Audit Quality.

\section{References}

Agoglia, C. P., Beaudoin, C., \& Tsakumis, G. T. (2009). The effect of documentation structure and task-specific experience on auditors' ability to identify control weaknesses. Behavioral Research in Accounting, 21(1), 1-17.

Al-Ajmi, J. (2009). Audit firm, corporate governance, and audit quality: Evidence from Bahrain. Advances in Accounting, incorporating Advances in International Accounting, 25, 64-74.

Alderman, C. W., \& Deitrick, J. W. (1982). Auditors' perceptions of time budget pressures and premature sign-offs: A replication and extension. Auditing: A Journal of Practice and Theory, 1(2), 54-68.

Aldhizer, G. R., Miller, J. R., \& Moraglio, J. F. (1995). Common attributes of audit quality. Journal of Accountancy, 179(1), 61-68.

Arnold, V., \& Sutton, S. G. (1998). The theory of technology dominance: Understanding the impact of intelligent aids on decision maker's judgments. Advances in Accounting Behavior Research, 1, 175-194.

Asare, S. K., \& Wright, A. M. (2004). The effectiveness of alternative risk assessment and program planning tools in a fraud setting. Contemporary Accounting Research, 21(Summer), 325-352.

Ashton, R. H., \& Ashton, A. H. (1995). Judgment and decision making research in accounting and auditing. New York: Cambridge University Press.

Bamber, E. M., \& Snowball, D. (1988). An experimental study of the effects of audit structure in uncertain environments. The Accounting Review, 63(3), 490-504.

Beattie, V., \& Fearnley, S. (1995). The importance of audit firm characteristics and the drivers of auditor change in uk listed companies. Accounting and Business Research, 25(100), 227-239.

Beattie, V., Fearnley, S., \& Hines T. (2011). Factors affecting audit quality in the 2007 UK regulatory environment: perceptions of chief financial officers, 
audit committee chairs and audit engagement partners. Discussion Paper 2011-13. Retrieved from http/ / www.gla.ac.uk/

Becker, C. L., Defond, M. L., Jiambalvo, J., \& Subramanyam, K. R. (1998). The effect of audit quality on earnings management. Contemporary Accounting Research, 15(1), 1-24.

Behn, B. K., Carcello, J. V., Hermanson, D. R., \& Hermanson, R. H. (1997). The determinants of audit client satisfaction among clients of Big 6 firms. Accounting Horizons, 11(1), 7-24.

Bell, T. B., Causholli, M., \& Knechel, W. R. (2015). Audit firm tenure, nonaudit services, and internal assessments of audit quality. Journal of Accounting Research, 53(3), 461-509.

Bliss, M. A., Gul, F. A., \& Majid, A. (2011). Do political connections affect the role of independent audit committees and CEO duality? some evidence from Malaysian audit pricing. Journal of Contemporary Accounting and Economics, 7(2), 82-98.

Brown, V. L., Gissel, J. L., \& Neely, D. G. (2016). Audit quality indicators: Perceptions of junior-level auditors. Managerial Auditing Journal, 31(8/9), 949-980.

Brown-Liburd, H., Issa, H., \& Lombardi, D. (2015). Behavioral implications of big data's impact on audit judgment and decision making and future research directions. Accounting Horizons, 29(2), 451-468.

Bryan, D. B., \& Reynolds, J. K. (2016). Auditor size and the cost of equity capital over auditor tenure. International Journal of Auditing, 20(3), 278-294.

Cahan, S. F., \& Sun, J. (2015). The effect of audit experience on audit fees and audit quality. Journal of Accounting, Auditing and Finance, 30(1), 78-100.

Caramanis, C., \& Lennox, C. (2008). Audit effort and earnings management. Journal of Accounting and Economics, 45(1), 116-138.

Carcello, J. V., \& Hermanson, R. H. (1995). Temporal changes in bankruptcy-related reporting. Auditing: A Journal of Practice and Theory, 14(2), 133-143.

Carcello, J. V., Hermanson, R. H., \& McGrath, N. T. (1992). Audit quality attributes: The perceptions of audit partners, preparers, and financial statement users. Auditing: A Journal of Practice, 11(1), 1-15.

Chen, C. J. P., Shome, A., \& Su, X. (2001). How is audit quality perceived by Big 5 and local auditors in China? A preliminary investigation. International Journal of Auditing, 5(1), 157-175. 
Chen, K. Y., Lin, K. L., \& Zhou, J. (2005). Audit quality and earnings management for Taiwan IPO firms. Managerial Auditing Journal, 20(1), 86-104.

Chin, C., \& Chi, H. (2009). Reducing restatements with increased industry expertise. Contemporary Accounting Research, 26(3), 729-765.

Cook, M. (1987). Two years of progress in financial accounting and reporting- February 1985 to January 1987. Journal of Accountancy, 163(6), 96-108.

Curtis, E., (2006). Business Risk Audit: A Study of the Relationship between Audit Methodology, Audit Practice and Audit Standards. University of Manchester, Manchester.

Cushing, B., \& Loebbecke, J. K. (1986). Comparison of audit methodologies of large accounting firms. Sarasota: American Accounting Association.

Daniels, B. W., \& Booker, Q. (2011). The effects of audit firm rotation on perceived auditor independence and audit quality. Research in Accounting Regulation, 23(1), 78-82.

Davidson, R. A., \& Neu, D. (1993). A note on the association between audit firm size and audit quality. Contemporary Accounting Research, 9(2), 479-488.

DeAngelo, L. E. (1981a). Auditor size and audit quality. Journal of Accounting and Economics, 3(1), 183-199.

DeAngelo, L. E. (1981b). Auditor independence, 'low balling', and disclosure regulation. Journal of Accounting and Economics, 3(2), 113127.

DeFond, M. L., \& Lennox, C. S. (2011). The effect of SOX on small auditor exits and audit quality. Journal of Accounting and Economics, 52(1), 2140.

DeFond, M. L., Raghunandan, K., \& Subramayam, K. R. (2002). Do nonaudit service fees impair auditor independence? Evidence from Going Concern Audit Opinions. Journal of Accounting Research, 40(4), 1247-1274.

Deis, D. R., \& Giroux, G. A. (1992). Determinants of audit quality in the public sector. The Accounting Review, 67(3), 462-479.

Dowling, C., \& Leech, S. A. (2014). A Big 4 firm's use of information technology to control the audit process: How an audit support system is changing auditor behavior. Contemporary Accounting Research, 31(1), 230-252.

Duff, A. (2004). AUDITQUAL: Dimensions of Audit Quality. Institute of Chartered Accountants of Scotland, Edinburgh. 
Duff, A. (2009). Measuring audit quality in an era of change. An empirical investigation of UK audit market stakeholders in 2002 and 2005. Managerial Auditing Journal, 24(5), 400-422.

Dye, R. (1993). Auditing standards, legal liability and auditor wealth. Journal of Political Economy, 101(5), 887-914.

Earley, C. E. (2002). The differential use of information by experienced and novice auditors in the performance of ill-structured audit tasks. Contemporary Accounting Research, 19(4), 595-614.

Eining, M. M., Donald, R. J., \& James, K. L. (1997). Reliance on decision aids: An examination of auditors' assessment of management fraud. Auditing-A Journal of Practice and Theory, 16(2), 1-19.

Elitzur, R. and Falk, H. (1996). Planned audit quality. Journal of Accounting and Public Policy, 15(3), 249-269.

Eshleman, J. D., \& Guo, P. (2014). Abnormal audit fees and audit quality: The importance of considering managerial incentives in tests of earnings management. Auditing: A Journal of Practice and Theory, 33(1), 117-138.

Feroz, E. H., Park, K., \& Pastena, V. S. (1991). The financial and market effects of the SEC's Accounting and Auditing Enforcement Releases. Journal of Accounting Research, 29(3),107-142.

Fontaine, R., Khemakhem, H., \& Herda, D. N. (2016). Audit committee perspectives on mandatory audit firm rotation: Evidence from Canada. Journal of Management and Governance, 20(3), 485-502.

Francis, J. R. (2011). A Framework for understanding and researching audit quality. Auditing: A Journal of Practice and Theory, 30(2), 125-152.

Frankel, R. M., Johnson, M. F., \& Nelson, K. K. (2002). The relation between auditors' fees for non-audit services and earnings management. The Accounting Review, 77(4), 71-105.

Financial Reporting Council (FRC) (2007). Promoting Audit Quality. London: Financial Reporting Council.

Financial Reporting Council (FRC) (2008a). The Audit Quality Framework. London: Financial Reporting Council.

Financial Reporting Council (FRC) (2008b). Guidance on Audit Committees. Retrieved from http://www.frc.org.uk/

Ghosh, A., \& Moon, D. (2005). Auditor tenure and perceptions of audit quality. The Accounting Review, 80(2), 585-612.

Gonthier-Besacier, N., Hottegindre, G., \& Fine-Falcy, S. (2016). Audit quality perception: Beyond the role-perception gap. International Journal of Auditing, 20(2), 186-201.

Gramling, A. A. (1999). External auditors' reliance on work performed by internal auditors: The influence of fee pressure on this reliance 
decision. Auditing: A Journal of Practice and Theory, 18(Supplement), 117-135.

Gul, F. A., Sun, S. Y. J., \& Judy S. L. T. (2003). Audit quality, earnings, and the Shanghai stock market reaction. Journal of Accounting, Auditing and Finance, 18(3), 411-427.

Guy, D. F., Ahmed, M. A. M., \& Randal, J. E. (2010). Audit quality attributes, client size and cost of equity capital. Review of Accounting and Finance, 9(4), 363-381.

Herrbach, O. (2001). Audit quality, auditor behaviour and the psychological contract. The European Accounting Review, 10(4), 787802.

Hoitash, R., Markelevich, A., \& Barragato, C. A. (2007). Audit fees and audit quality. Managerial Auditing Journal, 22(8), 761-786.

Humphrey, C. (1997). Current Issues in Auditing. In M. Sherer \& S. Turley (Eds.), Debating audit expectations (3rd ed., pp. 3-30). London: Paul Chapman Ltd.

Humphrey, C. (2008). Auditing research: A review across the disciplinary divide. Accounting, Auditing and Accountability Journal, 21(2), 17-203.

Humphrey, C., Moizer, P., \& Turley, S. (1992). The audit expectations gap-plus ca change, plus c'est la meme chose? Critical Perspectives on Accounting, 3(2), 137-161.

International Auditing and Assurance Standards Board (IAASB). (2014). A framework for audit quality, key elements that create environment for audit quality. Retrieved from https://www.ifac.org/

Institute of Chartered Accountants in England and Wales (ICAEW) (2008). Audit regulations and guidance. London: ICAEW.

Icerman, R. C., \& Hillison, W. A. (1991). Disposition of audit-detected errors: Some evidence on evaluative materiality. Auditing: A Journal of Practice and Theory, 10(1), 22-34.

Institute of Chartered Accountants in England and Wales (ICAEW) (2002). Audit Quality. London: Institute of Chartered Accountants in England and Wales (ICAEW) Auditing and Assurance Faculty.

Johnson, V. E., Khurana, I. K. \& Reynolds, J. K. (2002). Audit-firm tenure and the quality of financial reports. Contemporary Accounting Research, 19(4), 637-660.

Kang, Y. J., Trotman, A. J., \& Trotman, K. T. (2015). The effect of an audit judgment rule on audit committee members' professional skepticism: The case of accounting estimates. Accounting, Organizations and Society, 46, 59-76. 
Kelley, T., \& Margheim, L. (1990). The impact of time budget pressure, personality, and leadership variables on dysfunctional auditor behaviour. Auditing: A Journal of Practice and Theory, 9(2), 21-42.

Kelley, T., Margheim, L. \& Pattison, D. (1999). Survey on the differential effects of time deadline pressure versus time budget pressure on auditor behaviour. The Journal of Applied Business Research, 15(4), 117128.

Kim, J.-B., Chung, R., \& Firth, M. (2003). Auditor conservatism, asymmetric monitoring, and earnings management. Contemporary Accounting Research, 20(2), 323-359.

Kinney, W. R., Palmrose, Z. V., \& Scholz, S. (2004). Auditor independence, non-audit services, and restatements: Was the U.S. government right? Journal of Accounting Research, 42(3), 561-588.

Knapp, M.C. (1991). Factors that audit committee members use as surrogates for audit quality. Auditing: A Journal of Practice and Theory, 10(1), 35-52.

Knechel, W. R., Krishnan, G. V., Pevzner, M., Shefchik, L. B., \& Velury, U. K. (2013). Audit quality: Insights from the Academic Literature. Auditing: A Journal of Practice and Theory, 32(Supplement 1), 385-421.

Krishnan, J., \& Schauer, P. C. (2000). The differentiation of quality among auditors: Evidence from the not-for-profit sector. Auditing: A Journal of Practice and Theory, 19(2), 9-25.

Krishnan, J. \& Schauer, P. C. (2001). Differences in quality among audit firms. Journal of Accountancy, 192(1), 85-85.

Lee, B., \& Humphrey, C. (2006). More than a numbers game: qualitative research in accounting. Management Decision, 44(2), 180-197.

Lee, B. (2002). Professional socialisation, commercial pressures and junior staff's time-pressured irregular auditing- A contextual interpretation. British Accounting review, 34(4), 315-333.

Lehmann, C. M., \& Norman, C. S. (2006). The effects of experience on complex problem representation and judgment in auditing: An experimental investigation. Behavioral Research in Accounting Regulation, 18(1), 65-83.

Libby, R., \& Luft, J. (1993). Determinants of judgment performance in accounting settings: Ability, knowledge, motivation, and environment. Accounting, Organizations and Society, 18(5), 425-450.

Lightner, S. M., Adams, S. J., \& Lightner, K. M. (1982). The influence of situational, ethical, and expectancy theory variables on accountants' underreporting behavior. Auditing: A Journal of Practice and Theory, 2(1), 1-12. 
Li, K., \& Chen, Y. (2011). The effects of pre-client industry experience on restatement at the audit partner level and audit team level. Working paper, Ming-Chuan University and National Taiwan University.

Lord, A. T. \& DeZoort, F. T. (2001). The impact of commitment and moral reasoning on auditors' responses to social influence pressure. Accounting, Organizations and Society, 26(3), 215-235.

Lowensohn, S., Johnson, L. E., Elder, R. J., \& Davies, S. P. (2007). Auditor specialization, perceived audit quality, and audit fees in the local government audit market. Journal of Accounting and Public Policy, 26(6), 705-732.

Mala, R., \& Chand, P. (2015). Judgment and decision-making research in auditing and accounting: Future research implications of person, task, and environment perspective. Accounting Perspectives, 14(1), 150.

Malone, C. F. \& Roberts, R. W. (1996). Factors associated with the incidence of reduced audit quality behaviors. Auditing: A Journal of Practice and Theory, 15(2), 49-64.

Manry, D. L., Mock, T. J. and Turner, J. L. (2008). Does increased audit partner tenure reduce audit quality? Journal of Accounting, Auditing and Finance, 23(4), 553-572.

Margheim, L., \& Pany, K. (1986). Quality control, premature signoff, and underreporting of time: Some empirical findings. Auditing: A Journal of Practice and Theory, 5(2), 50-63.

Mautz, R. K. \& Sharaf, H. A. (1961). The Philosophy of Auditing: American Accounting Association, Sarasota.

McConnell, D. K. \& Banks, G.Y. (1998). A common peer review problem. Journal of Accountancy, 185(6), 39-44.

McNair, C. J. (1991). Proper compromise: The management control dilemma in public accounting and its impact on auditor behaviour. Accounting, Organizations and Society, 16(7), 635-653.

Mills, S. K. \& Bettner, M. S. (1992). Ritual and conflict in the audit profession. Critical Perspectives on Accounting, 3(2), 185-200.

Morris, M. H. \& Nichols, W. D. (1988). Consistency exceptions: materiality judgments and audit firm structure. The Accounting Review, 63(2), 237-254.

Mutchler, J. F. \& Williams, D. D. (1990). The relationship between audit technology, client risk profiles, and the going concern opinion decision. Auditing: A Journal of Practice and Theory, 9(3), 39-54.

$\mathrm{Ng}$, T. B., \& Tan, H. T. (2003). Effects of authoritative guidance availability and audit committee effectiveness on auditors' 
judgments in an auditor-client negotiation context. The Accounting Review, 78(3), 801-818.

Nelson, M., \& Tan, H.T. (2005). Judgment and decision making research in auditing: a task, person, and interpersonal interaction perspective. Auditing: A Journal of Practice and Theory, 24(Supplement), 41-71.

Nolder, C., \& Riley, T. J. (2014). Effects of differences in national culture on auditors' judgments and decisions: A literature review of crosscultural auditing studies from a judgment and decision making perspective. Auditing: A Journal of Practice and Theory, 33(2), 141-164.

Otley, D. T., \& Pierce, B. J. (1995). The control problem in public accounting firms: An empirical study of the impact of leadership style. Accounting, Organizations and Society, 20(5), 405-420.

Otley, D. T., \& Pierce, B. J. (1996a). Auditor time budget pressure: consequences and antecedents. Accounting, Auditing and Accountability Journal, 9(1), 31-58.

Otley, D. T., \& Pierce, B. J. (1996b). The operation of control systems in large audit firms. Auditing: A Journal of Practice and Theory, 15(2), 6584.

Palmrose, Z. V. (1988). An analysis of auditor litigation and audit service quality. The Accounting Review, 63(1), 55-73.

Percy, J. P. (2007). Fifteen years of reformation-what next? Managerial Auditing Journal, 22(2), 226-235.

Peytcheva, M., \& Gillett, P. R. (2012). Auditor perceptions of prior involvement and reputation threats as antecedents of quality threatening audit behavior. Managerial Auditing Journal, 27(9), 796820.

Pierce, B., \& Sweeney, B. (2003). Auditor responses to cost controls. The Irish Accounting Review, 10(1), 45-68.

Pierce, B., \& Sweeney, B. (2004). Cost-quality conflict in audit firms: An empirical investigation. European Accounting Review, 13(3), 415-441.

Pierce, B., \& Sweeney, B. (2005). Management control in audit firmspartners' perspectives. Management Accounting Research, 16(3), 340370.

Porter, B. A. (1991). Narrowing the audit expectation-performance gap: A Contemporary approach. Pacific Accounting Review, 3(1), 1-36.

Porter, B. A. (1993). An empirical study of audit expectation-performance gap. Accounting and Business Research, 24(93), 49-68.

Power, M. (1997). The audit society: Rituals of verification. Oxford, UK: Oxford University Press. 
Rasmussen, B. W., \& Jensen, L. (1998). Quality dimensions in external audit services-An external user perspective. The European Accounting Review, 7(1), 65-82.

Ruiz-Barbadillo, E., Gomez-Aguilar, N., Fuentes-Barbera, C. D., \& Garcia-Beneu, M.A. (2004). Audit quality and the going-concern decision-making process: Spanish evidence. European Accounting Review, 13(4), 597-620.

Schroeder, M. S., Solomon, I., \& Vickrey, D. (1986). Audit quality: The perceptions of audit-committee chairpersons and audit partners. Auditing: A Journal of Practice and Theory, 5(2), 86-94.

Shockley, R. A. (1982). Perceptions of audit independence: A conceptual model. Journal of Accounting, Auditing and Finance, 5(2), 126-143.

Sikka, P., Puxty, A., Willmott, H., \& Cooper, C. (1998). The impossibility of eliminating the expectation gap: Some theory and evidence. Critical Perspectives on Accounting, 9(3), 299-330.

Simnett, R., Carson, E., \& Vanstraelen, A. (2016). International archival auditing and assurance research: Trends, methodological issues, and opportunities. Auditing: A Journal of Practice and Theory, 35(3), 1-32.

Simunic, D. A. (1984). Auditing, consulting, and auditor independence. Journal of Accounting Research, 22(2), 679-702.

Smith, J. L. (2012). Investors' perceptions of audit quality: Effects of regulatory change. Auditing: A Journal of Practice and Theory, 31(1), 1738.

Solomon, I., \& Trotman, K. T. (2003). Experimental judgment and decision research in auditing: The first 25 years of AOS. Accounting, Organizations and Society, 28(4), 395-412.

Stanley, J. D., \& Todd DeZoort, F. (2007). Audit firm tenure and financial restatements: An analysis of industry specialization and fee effects. Journal of Accounting and Public Policy, 26(2),131-159.

Sucher, P., Moizer, P., \& Zarova, M. (1998). Factors affecting the assessment of the quality of a company's auditors: The case of the Czech Republic. International Journal of Auditing, 2(1), 7-20.

Sundgren, S., \& Svanström, T. (2014). Auditor-in-charge characteristics and going concern reporting. Contemporary Accounting Research, $31(2), 531-550$.

Sutton, S. G. (1993). Toward an understanding of the factors affecting the quality of the audit process. Decision Sciences, 24(1), 88-105.

Sweeney, B., \& Pierce, B. (2004). Management control in audit firms a qualitative examination. Accounting, Auditing and Accountability Journal, 17(5), 779-812. 
Tie, R. (1999). Concerns over auditing quality complicate the future of accounting. Journal of Accountancy, 188(6),14-15.

Wallace, W.A. (1980). The economic role of the audit in free and regulated markets. New York: Touce Ross and Co.

Watkins, A.L., Hillison, W., \& Morecroft, S.E. (2004). Audit quality: A synthesis of theory and empirical evidence. Journal of Accounting Literature, 23(1), 153-193.

Wilcox, K. A., \& Smith, C. H. (1977). Role discrepancies and the auditorclient relationship. Accounting, Organizations and Society, 2(1), 81-97.

Wilks, T. J., \& Zimbelman, M. F. (2004). Decomposition of fraud-risk assessments and auditors' sensitivity to fraud cues. Contemporary Accounting Research, 21(Fall), 719-745.

Willett, C., \& Page, M. (1996). A survey of time budget pressure and irregular auditing practices among newly qualified UK chartered accountants. British Accounting Review, 28(2), 101-120.

$\mathrm{Wu}, \mathrm{M}$. G. H. (2006). An economic analysis of audit and nonaudit services: The trade-off between competition crossovers and knowledge spillovers. Contemporary Accounting Research, 23(2), 527554. 